\title{
ANALISIS BERPIKIR PSEUDO SISWA IQ NORMAL DALAM PEMECAHAN MASALAH MATEMATIKA
}

\author{
Teguh Wibowo ${ }^{1}$, Riawan Yudi Purwoko ${ }^{2}$, Tri Swaraswati ${ }^{3}$ \\ ${ }^{1,2,3}$ Universitas Muhammadiyah Purworejo \\ Corresponding Author: tryswaraswati@gmail.com ${ }^{3}$
}

\begin{abstract}
This study aims to describe the occurrence of pseudo thinking of high school students who have a normal IQ in solving the mathematical problems in the material Position and Distance from Point, Line, and Field. This research is a qualitative study with a phenomenological approach. Data were collected by through giving tests and verification with interviews. The subject is taken using the snowball technique. The research subjects were students who had a normal IQ (80-119). Where subject who have a normal IQ in this research are two students. The data analysis techniques used is data reduction, data presentation, and conclusion. Based on the results of the analysis it was found that high school students with normal IQ have a low understanding of the concepts in Geometry (Position and Distance from Points, Line, and Fields).
\end{abstract}

Keywords: Pseudo thinking; Mathematical problems solving; IQ normal

How to cite: Kusuma, A. C. \& Mujiono, D. S. (2019). Analisis Berpikir Pseudo Siswa IQ Normal dalam Pemecahan Masalah Matematika. JRPM (Jurnal Review Pembelajaran Matematika), 4(2), 115-127.

\section{PENDAHULUAN}

Proses berpikir dalam pemecahan masalah merupakan hal penting untuk mendapat perhatian pendidik terutama dalam membantu siswa agar dapat mengembangkan kemampuannya dalam memecahkan masalah. King (2016) menyatakan bahwa secara formal, berpikir melibatkan proses penggunaan informasi secara mental dengan cara membentuk konsep, memecahkan masalah, mengambil keputusan, dan memperlihatkannya dalam cara yang kritis atau kreatif. Pemecahan masalah merupakan bagian yang terpadu dari seluruh pembelajaran matematika dan bagian yang tidak terpisahkan dari program pembelajaran.

Proses pembelajaran matematika dan pemahaman konsep merupakan bagian yang sangat penting untuk berpikir dalam memecahkan permasalahan matematika maupun permasalahan sehari-hari. Kesumawati (2008) menyatakan berpikir secara matematis berarti: (1) mengembangkan suatu pandangan matematis, menilai proses dari matematisasi dan abstraksi, dan memiliki kesenangan untuk menerapkannya, (2) mengembangkan kompetensi, dan menggunakannya dalam pemahaman matematis. Implikasinya adalah bagaimana seharusnya guru merancang pembelajaran dengan baik, pembelajaran dengan karakteristik yang bagaimana sehingga mampu membantu siswa membangun pemahamannya secara bermakna. Hal ini menguatkan bahwa berpikir dalam matematika merupakan hal yang sangat penting untuk mengetahui seberapa jauh pemahaman yang dimiliki oleh seseorang (siswa) 
dan mengembangkan potensi yang dimiliki untuk bisa berargumen. Siswa yang benar-benar berpikir secara matematis dapat diselidiki proses yang terjadi di dalam otaknya melalui wawancara yang dilakukan dan jawaban yang tampak dari hasil kerja yang dilakukan.

Aktifitas dalam proses pembelajaran matematika, masih banyak ditemukan pendidik matematika yang lebih menekankan pada prosedur, aturan, dan cara menyelesaikan soal. Hal tersebut mengakibatkan siswa hanya menjalankan langkah-langkah yang telah dicontohkan oleh gurunya, tanpa mengetahui mengapa prosedur tersebut sesuai. Selain itu apabila siswa menemukan soal yang berbeda dengan apa yang telah dicontohkan oleh gurunya, maka siswa tersebut akan merasa kesulitan dalam mengerjakannya. Siswa juga sering menerapkan prosedur yang salah dalam menyelesaikan soal, dianggapnya soal itu sama, padahal konteksnya berbeda, sehingga jawaban yang diperoleh menjadi salah. Wibawa (2016), mengungkapkan bahwa proses belajar mengajar guru cenderung kurang memberikan penekanan pada mengapa suatu prosedur dilakukan dan apa arti dari jawaban yang diberikan. Akibatnya siswa mengalami sebuah keraguan dalam hal pemahaman dimana ketika diberikan soal atau masalah dengan tipe yang sama siswa akan kembali berpikir, prosedur mana yang harus digunakan dan apakah prosedur yang digunakan benar atau tidak. Tentunya ini akan menjadi perdebatan dalam proses berpikir siswa.

Perilaku siswa tersebut ketika memecahkan masalah dapat direkam dan dianalisis untuk menentukan proses kognitif tentang yang dipikirkan seseorang, dan pemahaman konsep yang terkait dengan masalahnya. Menurut Vinner (1997), kebanyakan siswa beranggapan bahwa dirinya telah melakukan proses berpikir dalam menyelesaikan masalah, padahal dia hanya menirukan yang dilakukan oleh guru. Keadaan seperti ini diungkapkan Vinner sebagai berpikir pseudo, suatu keadaan dimana siswa tidak benar-benar menggunakan pikirannya untuk menyelesaikan suatu masalah.

Penelitian berkaitan dengan proses berpikir pseudo seseorang (siswa) dalam pembelajaran matematika telah banyak dikaji oleh peneliti, Vinner (1997) dalam hasil penelitiannya menjelaskan tentang proses berpikir pseudo analitik dan pseudo konseptual sebagai kesalahan siswa dalam menyelesaikan soal matematika. Wibawa (2016) menemukan cara mendefragmentasi struktur berpikir siswa yang pseudo-salah melalui pemetaan kognitif dalam memecahkan masalah limit fungsi. Mendefragmentasi atau merestrukturisasi yang dilakukan bertujuan untuk memperbaiki kesalahan berpikir siswa dalam memecahkan masalah.

Subanji (2011), memaparkan bahwa berpikir pseudo dapat dilihat dari jawaban yang 
diberikan oleh siswa. Identifikasi yang dilakukan mengarah pada dua istilah yaitu berpikir pseudo benar dan berpikir pseudo salah. Berpikir pseudo benar yaitu jawaban benar tetapi siswa tidak dapat menjustifikasi jawabannya sedangkan berpikir pseudo salah yaitu jawaban salah tetapi siswa mampu menyelesaikannya secara benar setelah melakukan refleksi.

Vinner (1997) menjelaskan bahwa berpikir pseudo terjadi karena dalam memecahkan masalah, siswa terpaksa mempelajari topik-topik dan memecahkan masalah-masalah tertentu tetapi tidak melakukan kontrol terhadap apa yang ia pikirkan, sehingga Husnah (2018) berpendapat bahwa siswa sering mengatur kembali informasi yang dimiliki, membangun kembali argumen, dan mencari konteks yang berbeda untuk memverifikasi ide-ide mereka. Oleh karena itu, berpikir pseudo bukanlah dari proses berpikir siswa yang sebenarnya, melainkan berasal dari proses berpikir semu atau samar yang terjadi ketika siswa belajar maupun ketika meyelesaikan masalah. Berpikir pseudo pertama kali dikenalkan oleh Vinner melalui artikelnya. Vinner mengungkapkan bahwa dalam pembelajaran matematika, siswa diharapkan mampu memikirkan tentang konsep, makna dan hubungannya, maka siswa dikatakan berada pada mode berpikir konseptual. Akan tetapi apabila siswa tidak melakukannya, tetapi berhasil dalam menghasilkan jawaban yang tampaknya konseptual , maka siswa dikatakan berada pada mode berpikir pseudo konseptual. Jika siswa bertindak sesuai dengan proses berpikir yang seharunya dalam memecahkan masalah matematika, maka siswa dikatakan berada pada mode berpikir analitik. Akan tetapi jika siswa tidak melakukannya dengan cara yang beragam, tetapi berhasil dalam membuat jawaban yang tampaknya analitik dalam memecahkan masalah maka ini akan digambarkan dalam mode berpikir pseudo analitik.

Proses berpikir pseudo sering timbul diakibatkan oleh kurangnya pemahaman siswa terhadap suatu konsep dan kemampuan berpikir siswa dalam memecahkan masalah. Setiap individu di dunia ini mempunyai perbedaan dengan individu yang lain. Begitu juga dalam hal kecerdasan, setiap individu (siswa) memiliki potensi yang berbeda pula. Rahmasari (2012) menjelaskan bahwa kecerdasan atau inteligensi adalah suatu kemampuan mental yang melibatkan proses berpikir secara rasional. Oleh karena itu, inteligensi tidak dapat diamati secara langsung, melaikan harus disimpulkan dari berbagai tindakan nyata yang merupakan manifestasi dari proses berpikir rasional itu. Berdasarkan pendapat di atas, dapat dikatakan bahwa kecerdasan terkait dengan kemampuan berpikir seseorang.

Pada kajian psikologi dijelaskan bahwa kecerdasan dapat diukur dan dikategorikan. Tingkat kecerdasan tersebut diukur dengan tes kecerdasan dan hasil pengukuran tersebut 
biasa disebut dengan IQ (Intelligence Quotient). Rohmatin (2012), menyebutkan ada sepuluh kategori kecerdasan berdasarkan nilai IQ, beragam dari yang paling rendah (dengan IQ 24 ke bawah yang disebut idiot) sampai ketegori paling tinggi (dengan IQ 140 ke atas yang disebut genius). Penelitian ini fokus pada analisis berpikir pseudo benar pada siswa IQ normal. Berpikir pseudo benar dan proses terjadinya perlu dianalisis karena ada kemungkinan besar siswa IQ normal tidak memahami dengan benar masalah apa yang sedang dihadapi, apabila hal ini dibiarkan guru akan menganggap bahwa siswanya benar-benar paham dengan apa masalah yang sedang dikerjakan. Kenyataannya siswa akan selalu di hadapkan dengan masalahmasalah matematika yang lebih konteks lagi. Materi yang mendukung dilakukannya penelitian ini adalah geometri (kedudukan dan jarak titik, garis, dan bidang). Tahap dalam menyelesaikan soal geometri (kedudukan dan jarak titik, garis, dan bidang) siswa cenderung mengalami kesulitan dalam memahami konsep yang sesungguhnya.

Berdasarkan dari uraian di atas, timbul kekhawatiran bahwa siswa akan mengalami proses berpikir pseudo dalam memecahkan masalah matematika, sehingga peneliti tertarik untuk melakukan penelitian dengan tujuan untuk mengetahui dan menganalisis berpikir pseudo siswa IQ normal dalam pemecahan masalah matematika.

\section{METODE PENELITIAN}

Penelitian ini merupakan penelitian kualitatif. Moleong (2014) menyatakan bahwa penelitian kualitatif adalah penelitian yang bermaksud untuk memahami fenomena tentang apa yang dialami oleh subjek penelitian, misalnya perilaku, persepsi, motivasi, tindakan dll secara holistik, dan dengan cara deskripsi dalam bentuk kata-kata dan bahasa, pada suatu konteks khusus yang alamiah dan dengan memanfaatkan berbagai metode alamiah. Penelitian ini dilaksanakan di Sekolah Menengah Atas (SMA) di SMA Negeri 1 Purworejo Jawa Tengah, dan waktu yang dilaksanakan dalam penelitian ini adalah enam bulan. Subjek dalam penelitian ini adalah siswa SMA Negeri 1 Purworejo Jawa Tengah kelas XII dengan kategori IQ normal tahun ajaran 2018/2019.

Pengambilan subjek dalam penelitian ini menggunakan teknik snowball sebanyak 2 subjek. Data dan sumber data diperoleh langsung dari subjek penelitian yang berupa: dokumentasi sertifikat tes $I Q$ kategori normal, tes pemecahan masalah, wawancara, dan think aloud. Tes pemecahan masalah dengan materi geometri (kedudukan dan jarak titik, garis, dan bidang) digunakan untuk mengetahui proses terjasinya berpikir pseudo siswa dalam memecahkan masalah matematika. Analisis data dalam penelitian ini mengacu pada model 
analisis data yang dikemukakan oleh Miles \& Huberman dalam Sugiyono (2016). Adapun langkah-langkah analisis data yang dimaksud meliputi data reduction, data display, dan verifycation.

\section{HASIL DAN PEMBAHASAN}

Soal yang diselesaikan oleh subjek dianalisis oleh peneliti sebagai berikut:

Sebuah Aquarium berbentuk kubus ABCD.EFGH dengan panjang rusuk $8 \mathrm{~cm}$. Berapa jarak dari titik E ke garis BD? Berikan alasannya!

\section{A. Subjek pertama $\left(S_{1}\right)$}

Tahap dalam mengerjakan pemecahan masalah kedudukan dan jarak titik, garis, dan bidang $\mathrm{S}_{1}$ tidak menuliskan apa yang diketahui dalam masalah, dan tidak menuliskan apa yang ditanyakan dalam masalah tersebut. $\mathrm{S}_{1}$ langsung menyelesaikan masalah tersebut dengan mengkonstruksi gambar kubus yang disajikan pada Gambar 1 berikut.

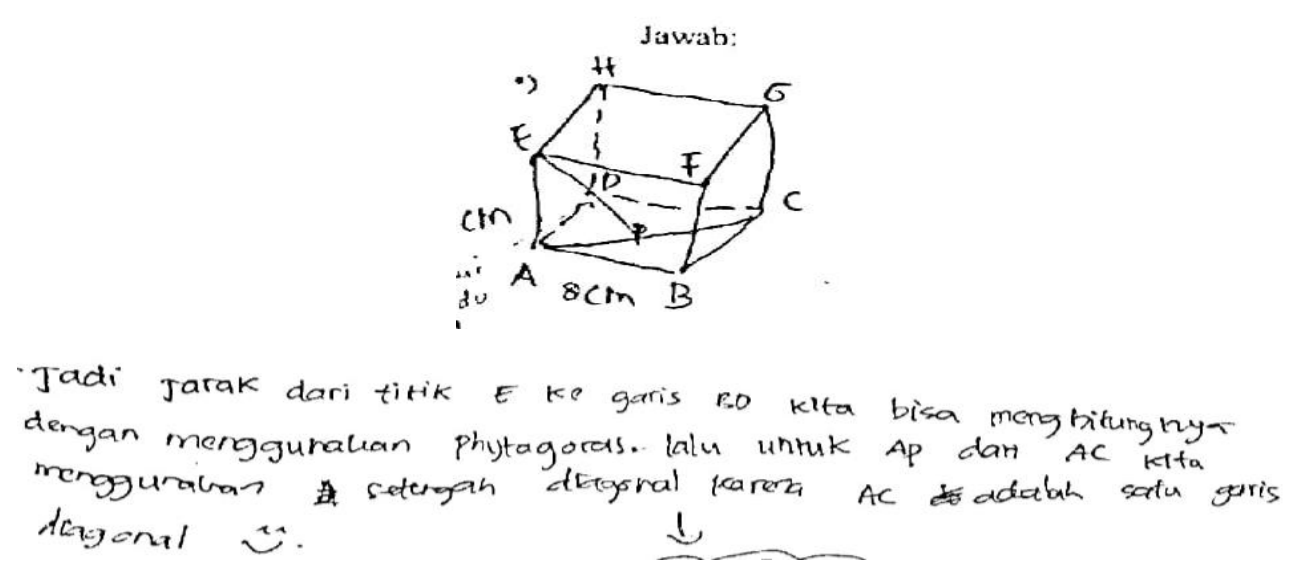

Gambar 1. Jawaban tertulis $S_{1}$ dalam mengkonstruksi kubus

Pada Gambar 1, $\mathrm{S}_{1}$ menggambar sebuah kubus sesuai dengan masalah yang diketahui. Karena yang ditanyakan adalah jarak titik $\mathrm{E}$ ke garis BD maka $\mathrm{S}_{1}$ terlebih dahulu menarik garis dari titik E ke titik tengah P pada garis BD yang sudah dibuat. Pada Gambar tampak bahwa $\mathrm{S}_{1}$ memberikan alasan "karena yang dicari jarak titik $\mathrm{E}$ ke garis $\mathrm{BD}$ bisa menghitungnya dengan menggunakan Pythagoras". Alasan yang diberikan $\mathrm{S}_{1}$ tentu saja kurang tepat, karena $S_{1}$ tidak dapat menjelaskan proses menggambar jarak dari titik $\mathrm{E}$ ke garis BD. $S_{1}$ dapat menggambar dengan benar karena $S_{1}$ hanya berpikir untuk memberikan jawaban yang benar berdasarkan pengalaman yang sudah didapatkannya. $S_{1}$ tidak memahami dengan benar, karena yang ditanyakan jarak titik E ke garis BD maka, jarak antara titik E dan garis BD pada bidang ABCD adalah panjang ruas garis EP jika P merupakan proyeksi E pada 
garis $\mathrm{BD}$. Hal tersebut menunjukkan bahwa $\mathrm{S}_{1}$ sedang berpikir pseudo dalam memahami konsep. Gambar yang dihasilkan $\mathrm{S}_{1}$ adalah tampak konseptual, namun gambar tersebut bukan diperoleh dari proses berpikir yang konseptual.

Hasil pekerjaan $S_{1}$ ini juga dapat dilihat melalui data think aloud $S_{1}$ dan diperkuat dengan wawancara. Berikut think aloud yang dimunculkan oleh $S_{2}$ saat mengerjakan pada menit ke 03:06-04:02: “jadi jarak dari titik E ke garis BD kita bisa menghitungnya dengan menggunakan Pythagoras". Berdasarkan data think aloud yang muncul, $\mathrm{S}_{1}$ mengalami berpikir pseudo dalam memahami konsep. $\mathrm{S}_{1}$ brerpikir sambil mengeluarkan suara bahwa untuk menarik jarak dari titik E ke garis BD digunakan konsep Phytagoras yang nantinya digunakan untuk menghitung jaraknya. Dengan demikian $\mathrm{S}_{1}$ mengalami proses berpikir yang tidak sesungguhnya atau berpikir semu, dianggapnya jawaban yang diberikan sudah benar padahal tidak sesuai dengan konsep yang sebenarnya. $\mathrm{S}_{1}$ terlihat hanya mempelajari hal-hal tertentu dan memecahkan masalah-masalah tertentu tapi tidak memahami secara mendalam apa yang dipikirkan. Data think aloud tersebut akan diperkuat oleh data wawancara. Berikut hasil wawancara yang dilakukan dengan $S_{1}$.

P : Tadi kan kamu menarik garis dari titik E ke titik P, nah itu bagaimana konsepnya kok bisa kamu gambarnya seperti itu?

$\mathrm{S}_{1}$ : Ya karena untuk mencari garis dari bangun kubus ini, kita harus menggunakan Phytagoras.

$\mathrm{P}$ : Nah kan carinya jarak dari titik E ke P kok bisa menarik garisnya seperti itu?

$\mathrm{S}_{1}$ : Iya karena guru yang mengajarkan seperti itu.

Setelah menggambar kubus, $\mathrm{S}_{1}$ menulis terlebih dahulu rumus atau konsep apa yang akan digunakan untuk mencari nilai AP. Berikut hasil pekerjaan $S_{1}$ disajikan pada Gambar 2 berikut.

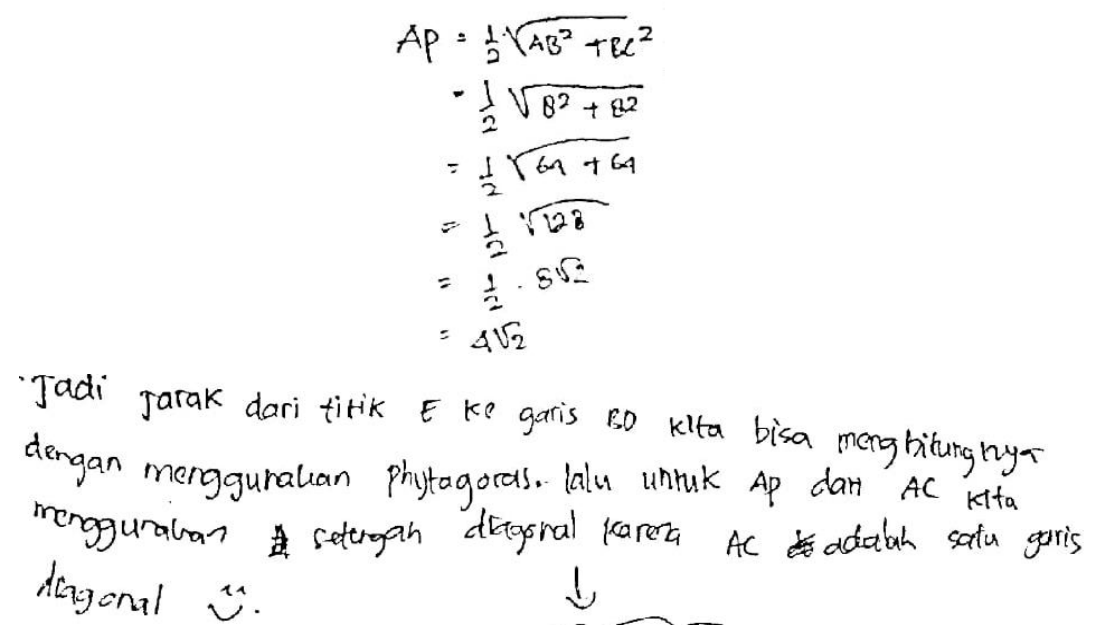

Gambar 2. Jawaban tertulis $S_{1}$ dalam memilih konsep 
$\mathrm{S}_{1}$ mencari nilai AP dengan menggunakan rumus $\mathrm{AP}=\frac{1}{2} \sqrt{A B^{2}+B C^{2}}$. Pada Gambar 2 tampak bahwa $S_{1}$ memberikan alasan "untuk mencari AP dari garis AC menggunakan setengah diagonal, karena AC adalah satu garis diagonal". Alasan yang diberikan $\mathrm{S}_{1}$ tentu saja kurang tepat, $\mathrm{S}_{1}$ menjawab bahwa $\mathrm{AP}=\frac{1}{2} \mathrm{AC}$ karena melihat dari gambar yang sudah dibuatnya bahwa yang $S_{1}$ tahu $A C$ adalah satu diagonal maka dapat disimpulkan bahwa AP setengah diagonal AC. $\mathrm{S}_{1}$ tidak tahu bahwa suatu bidang persegi memiliki sifat simetri, sehingga perpotongan diagonal sisinya akan membagi dua bidang yang kongruen. Hal tersebut menunjukan bahwa $\mathrm{S}_{1}$ sedang berpikir psendo dalam memahami konsep. Jawaban yang dihasilkan $\mathrm{S}_{1}$ adalah jawaban benar, namun jawaban tersebut bukan diperoleh dari proses berpikir yang benar.

Hasil pekerjaan $S_{1}$ ini juga dapat dilihat melalui data think aloud $S_{1}$ dan diperkuat dengan wawancara. Berikut think aloud yang dimunculkan oleh $S_{1}$ saat mengerjakan pada menit ke 04.03-04:43: "lalu untuk AP dari AC dapat menggunakan setengah diagonal, karena AC adalah satu garis diagonal". Berdasarkan data think aloud yang muncul, $\mathrm{S}_{1}$ mengalami berpikir pseudo dalam memahami konsep. $S_{1}$ brerpikir sambil mengeluarkan suara bahwa AP setengah AC karena garis AC itu satu diagonal jadi AP setengahnya diagonal AC. Dengan demikian $S_{1}$ mengalami proses berpikir yang tidak sesunguhnya atau berpikir semu, dianggapnya jawaban yang diberikan sudah benar padahal tidak sesuai dengan konsep yang sebenarnya. Data think aloud tersebut akan diperkuat oleh data wawancara. Berikut hasil wawancara yang dilakukan dengan $\mathrm{S}_{1}$.

$\mathrm{P}$ : Terus kenapa AP setengah AC?

$\mathrm{S}_{1}$ : Ya karena AP setengah diagonal AC (sambil menunjuk garis yang dibuat) dan ini titik pusatnya (sambil menunjuk titik $P$ pada gambar).

Berdasarkan jawaban $\mathrm{S}_{1}$ tersebut menunjukkan bahwa $\mathrm{S}_{1}$ sedang berpikir pseudo. Data wawancara di atas dapat memperjelas dan mengkonfirmasi atas munculnya think aloud.

\section{B. Subjek kedua $\left(\mathrm{S}_{2}\right)$}

Tahap dalam memecahkan masalah kedudukan dan jarak titik, garis, dan bidang $\mathrm{S}_{2}$ tidak menuliskan apa yang diketahui dalam masalah, dan tidak menuliskan apa yang ditanyakan dalam masalah tersebut. $\mathrm{S}_{2}$ langsung menyelesaikan masalah tersebut dengan mengkonstruksi Gambar kubus seperti tampak pada Gambar 3 berikut. 

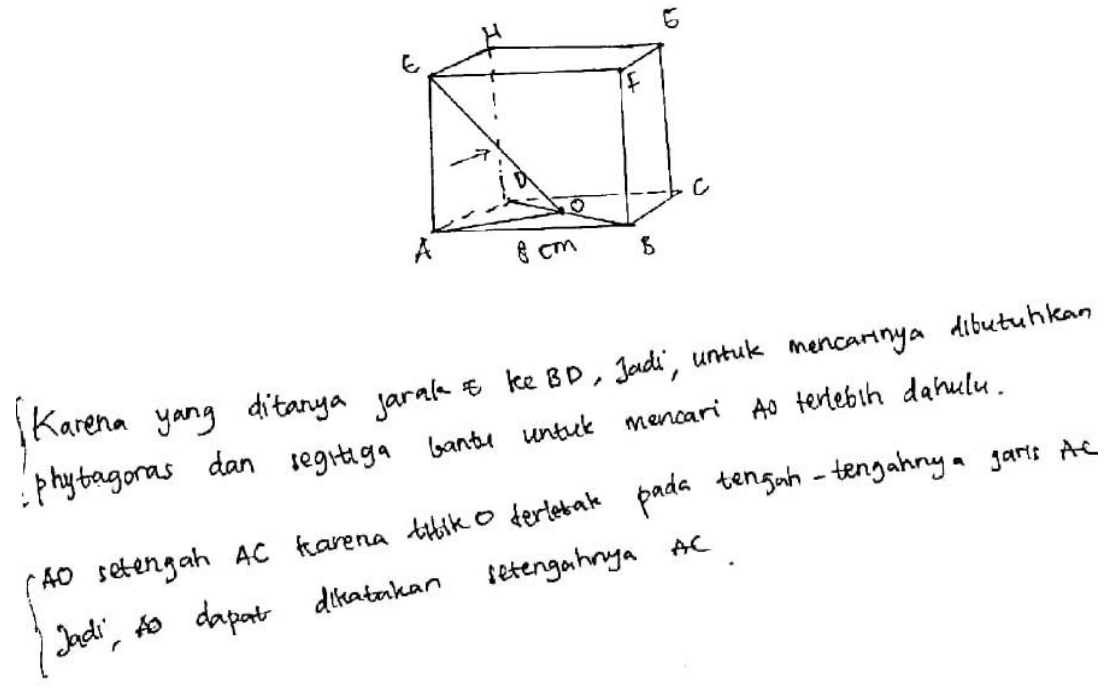

Gambar 3. Jawaban tertulis $S_{2}$ dalam mengkonstruksi kubus

Pada Gambar 3, $\mathrm{S}_{2}$ menggambar sebuah kubus sesuai dengan masalah yang diketahui. Adapun yang ditanyakan pada soal tersebut adalah jarak titik E ke garis BD maka $\mathrm{S}_{2}$ terlebih dahulu menarik garis dari titik E ke titik tengah O pada garis BD yang sudah dibuat. Pada Gambar 3 tampak bahwa $S_{2}$ memberikan alasan "karena yang ditanya jarak E ke BD jadi, untuk mencarinya dibutuhkan Phytagoras dan segitiga bantu untuk mencari AO terlebih dahulu". Alasan yang diberikan $S_{2}$ tentu saja kurang tepat, karena $S_{2}$ tidak dapat menjelaskan proses menggambar jarak dari titik $\mathrm{E}$ ke garis $\mathrm{BD} . \mathrm{S}_{2}$ dapat menggambar dengan benar karena $S_{2}$ beranggapan bahwa untuk menarik garis dari titik $E$ ke titik $O, S_{2}$ hanya menarik garis yang sesuai agar dapat ditemukan sebuah segitiga yang nantinya bisa dicari jaraknya dengan rumus Pythagoras. $S_{2}$ tidak memahami dengan benar, karena yang ditanyakan jarak titik $\mathrm{E}$ ke garis BD maka, jarak antara titik $\mathrm{E}$ dan garis BD pada bidang $\mathrm{ABCD}$ adalah panjang ruas garis $\mathrm{EO}$ jika $\mathrm{O}$ merupakan proyeksi E pada garis BD. Hal tersebut menunjukkan bahwa $\mathrm{S}_{2}$ sedang berpikir pseudo dalam memahami konsep. Gambar yang dihasilkan $\mathrm{S}_{2}$ adalah benar, namun gambar tersebut bukan diperoleh dari proses berpikir yang benar.

Hasil pekerjaan $S_{2}$ ini juga dapat dilihat melalui data think aloud $S_{2}$ dan wawancara. Berikut think aloud yang dimunculkan oleh $\mathrm{S}_{2}$ saat mengerjakan pada menit ke 05:22-05:59: "karena untuk mencarinya dibutuhkan Pythagoras dan segitiga bantu untuk mencari AO terlebih dahulu". Berdasarkan data think aloud yang muncul, $\mathrm{S}_{2}$ mengalami berpikir pseudo dalam memahami konsep. $\mathrm{S}_{2}$ berpikir sambil mengeluarkan suara bahwa untuk menarik jarak dari titik E ke garis BD di sesuaikan agar ditemukan sebuah segitiga yang digunakan untuk menghitung jaraknya dengan menggunakan rumus Pythagoras. Dengan demikian 
$\mathrm{S}_{2}$ mengalami proses berpikir yang tidak sesungguhnya atau berpikir semu, dianggapnya jawaban yang diberikan sudah benar padahal tidak sesuai dengan konsep yang sebenarnya. Data think aloud di atas akan diperkuat oleh data wawancara. Berikut hasil wawancara yang dilakukan dengan $\mathrm{S}_{2}$.

P : Tadi kan kamu menarik garis dari titik E ke titik P, nah itu bagaimana konsepnya kok bisa kamu gambarnya seperti itu?

$\mathrm{S}_{2}$ : Karena garis $\mathrm{BD}$ kan berarti $\mathrm{E}$ ke $\mathrm{BD}$, ya berarti untuk bisa mencari $\mathrm{E}$ ke $\mathrm{BD}$ berarti, $\mathrm{BD}$ adalah perwakilan garis yang bisa dikatakan dibagi dua. Nah berartikan perwakilan garisnya dikatakan AO.

$\mathrm{P}$ : Nah kan carinya jarak dari titik $\mathrm{E}$ ke $\mathrm{P}$ kok bisa menarik garisnya seperti itu?

$\mathrm{S}_{2}$ : Ya kalau sudah ada AO kan bisa ditarik garis dari titik E ke O supaya terbentuk segitiga ini (sambil menunjukkan gambar yang dibuat) untuk dicari jaraknya menggunakan Pythagoras.

Jawaban $\mathrm{S}_{2}$ tersebut menunjukkan bahwa $\mathrm{S}_{2}$ sedang berpikir pseudo. Data wawancara di atas dapat memperjelas dan mengkonfirmasi atas munculnya think aloud.

Setelah menggambar kubus, $S_{2}$ menulis terlebih dahulu rumus atau konsep apa yang akan digunakan untuk mencari nilai AO. Berikut hasil pekerjaan $\mathrm{S}_{2}$ yang tampak pada Gambar 4 berikut.

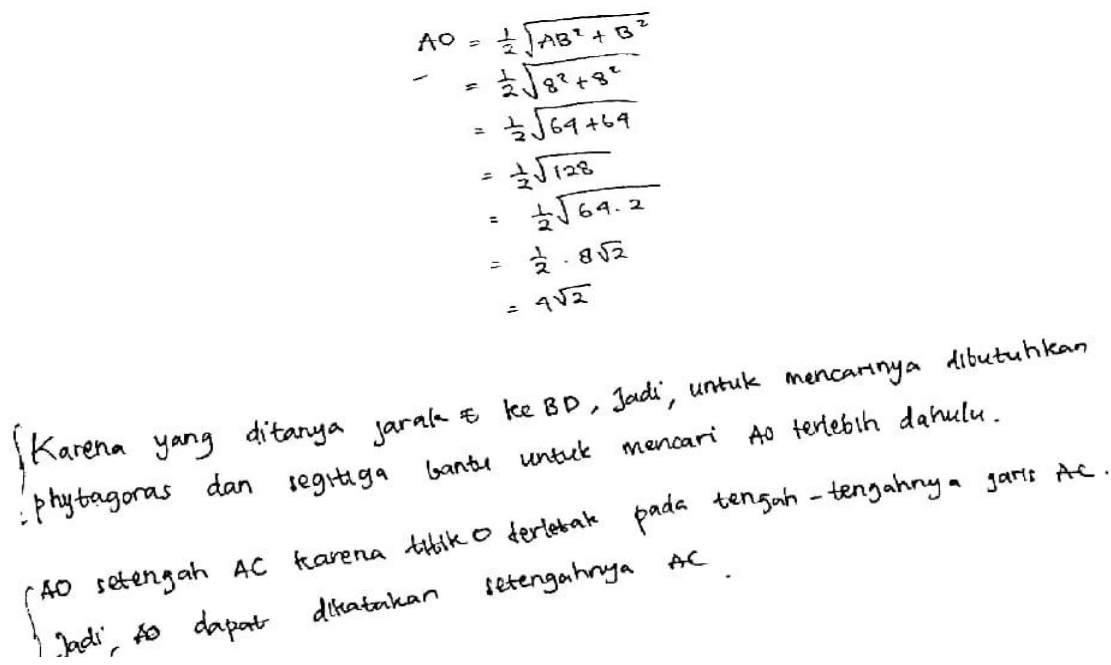

Gambar 4. Jawaban tertulis $S_{2}$ dalam memilih konsep

$\mathrm{S}_{2}$ mencari nilai $\mathrm{AO}$ dengan menggunakan rumus $\mathrm{AO}=\frac{1}{2} \sqrt{A B^{2}+B C^{2}}$. Gambar 4 tampak bahwa $\mathrm{S}_{2}$ memberikan alasan "AO setengah AC karena titik $\mathrm{O}$ terletak pada tengahtengahnya garis AC. Jadi, AO dapat dikatakan setengahnya AC”. Alasan yang diberikan $\mathrm{S}_{2}$ tentu saja kurang tepat, karena $\mathrm{S}_{2}$ menjawab bahwa $\mathrm{AO}=\frac{1}{2} \mathrm{AC}$ dengan melihat dari gambar yang sudah dibuatnya bahwa letak titik $\mathrm{O}$ ditengah-tengahnya garis $\mathrm{AC}$, sehingga $\mathrm{S}_{2}$ dapat menyimpulkan bahwa AO setengah AC. $\mathrm{S}_{2}$ tidak tahu bahwa suatu bidang persegi memiliki sifat simetri, sehingga perpotongan diagonal sisinya akan membagi dua bidang yang kongruen. Hal tersebut menunjukkan bahwa $S_{2}$ sedang berpikir psendo dalam memahami 
konsep.

Hasil pekerjaan $S_{2}$ ini juga dapat dilihat melalui data think aloud $\mathrm{S}_{2}$ dan diperkuat dengan wawancara. Berikut think aloud yang dimunculkan oleh $\mathrm{S}_{2}$ saat mengerjakan pada menit ke 06.01-06:44: "AO setengah dari AC karena O ditengah-tengahnya garis AC. Jadi AO dapat dikatakan setengahnya". Berdasarkan data think aloud yang muncul, $\mathrm{S}_{2}$ mengalami berpikir pseudo dalam memahami konsep. $\mathrm{S}_{2}$ berpikir sambil mengeluarkan suara bahwa AO setengah AC karena titik $\mathrm{O}$ berada ditengah-tengah garis AC jika dilihat dari Gambar yang sudah dibuat $\mathrm{S}_{2}$. Dengan demikian $\mathrm{S}_{2}$ mengalami proses berpikir yang tidak sesunnguhnya atau berpikir semu, diangapnya jawaban yang diberikan sudah benar padahal tidak sesuai dengan konsep yang sebenarnya. Data think aloud tersebut akan diperkuat oleh data wawancara. Berikut hasil wawancara yang dilakukan dengan $S_{2}$.

$\mathrm{P} \quad$ : Kenapa AO setengah AC?

$\mathrm{S}_{2}$ : Ya karena $\mathrm{O}$ ditengah-tengahnya AC, jadi AO setengahnya AC.

Jawaban $S_{2}$ tersebut menunjukkan bahwa $S_{2}$ sedang berpikir pseudo. Data wawancara di atas dapat memperjelas dan mengkonfirmasi atas munculnya think aloud.

Berdasarkan hal di atas $\mathrm{S}_{2}$ dengan IQ normal cenderung berpikir pseudo dalam memecahkan masalah matematika pada materi geometri (kedudukan dan jarak dari titik, garis, dan bidang). Subjek $I Q$ normal berpikir pseudo dalam pemecahan masalah. Hal ini dilihat dari jawaban siswa yang benar tetapi setelah diklarifikasi jawaban yang diberikan salah atau kurang tepat. Subjek dengan IQ normal memiliki pemahaman konsep yang rendah pada materi geometri (kedudukan dan jarak titik, garis, dan bidang) hal ini dibuktikan dari algoritma berpikir $S_{2}$ yaitu: (1) dapat merumuskan dan memberikan jawaban benar, yaitu jawaban yang tampak konseptual dengan menarik garis dari titik E ke garis BD yang ditanyakan dan menggunakan rumus $\mathrm{AO}=1 / 2 \mathrm{AC}$ untuk mencari nilai jarak yang ditanyakan (2) jawaban benar yang diperoleh tidak sesuai dengan pemahaman siswa, hal ini terjadi karena siswa beranggapan bahwa jawaban yang diberikan sudah sesuai dengan konsep jarak titik E ke garis BD dan sifat persegi adalah sama panjang, tegak lurus dan saling membagi dua sama besar. Siswa belum paham dengan benar konsep tersebut, (3) terjadi kesalahan dalam memberikan justifikasi pada jawaban benar yang diberikan, hal ini terjadi karena siswa belum dapat memahami konsep jarak titik $\mathrm{E}$ ke garis $\mathrm{BD}$ dan salah satu sifat persegi adalah diagonaldiagonalnya sama panjang, tegak lurus dan saling membagi dua sama besar.

Tahap merencanakan pemecahan masalah subjek telah mampu memilah konsep yang akan digunakan yaitu subjek menggunakan konsep Pythagoras untuk menyelesaikan masalah. 
Subjek menggunakan konsep Pythagoras tetapi tidak mampu memikirkan makna dalam masalah tersebut. Dalam merencanakan konsep subjek tampak berpikir konseptual. Subjek dapat memberi makna bahwa garis $\mathrm{AO}$ adalah setengah dari garis AC, karena subjek melihat langsung dari gambar (posisi titik $\mathrm{O}$ ditengah) dan menghubungkannya dengan nilai garis diagonal, subjek menganggap garis diagonal bernilai satu, karena titik $\mathrm{O}$ ditengah garis diagonal tesebut jadi nilainya setengah diagonal. Argumen subjek tersebut kurang sesuai dengan Siswoyo (2011), bahwa salah satu sifat dari persegi adalah diagonal-diagonalnya sama panjang, tegak lurus dan saling membagi dua sama besar. Subjek tidak mencari konteks yang berbeda untuk memverifikasi ide-ide mereka tentang sifat persegi yang memiliki makna dan hubungan dengan masalah yang dihadapi.

Pemahaman konsep yang dangkal tersebut diakibatkan dari proses berpikir siswa yang tidak terkontrol yang dinamakan berpikir pseudo konseptual. Hal ini sesuai dengan Vinner (1997) menjelaskan bahwa berpikir pseudo terjadi karena dalam memecahkan masalah, siswa terpaksa mempelajari topik-topik dan memecahkan masalah-masalah tertentu tetapi tidak melakukan kontrol terhadap apa yang ia pikirkan. Itulah yang dilakukan subjek dalam memecahkan masalah kedudukan dan jarak titik, garis, dan bidang tersebut.

Tahap melaksanakan masalah yang dilakukan subjek pertama kali yaitu mengkonstruksi kubus sesuai yang diketahui dan untuk mencari jarak, subjek menarik garis dari titik E ke garis $G$ yang ditanyakan, namun subjek tidak memahami konsep dalam pengonstruksiannya dengan benar. Subjek dapat mengkonstruksi titik E ke garis $G$ pada kubus karena menggunakan pengalaman sebelumnya yaitu mengaitkan konsep Pythagoras untuk menyelesaikannya dan subjek dapat mengkonstrukuksi kubus sesuai dengan yang pernah dicontohkan oleh gurunya. Pemikiran subjek tersebut kurang sesuai dengan Krismanto (2008) bahwa jarak titik dan garis $G$ adalah panjang ruas garis penghubung titik dengan proyeksi titik tersebut pada garis G. Subjek tidak dapat menjelaskan konsep menggambar jarak pada gambar kubus yang telah dibuatnya. Hal ini sesuai dengan pendapat Vinner (1997), kebanyakan siswa beranggapan bahwa dirinya telah melakukan proses berpikir dalam menyelesaikan masalah, padahal ia hanya meniru apa yang dilakukan oleh guru. Keadaan seperti ini diungkapkan Vinner sebagai berpikir pseudo, suatu keadaan dimana siswa tidak benar-benar menggunakan pikirannya untuk menyelesaikan suatu masalah. Subjek juga tidak melakukan kontrol terhadap apa yang dikerjakan, dia hanya mengerjakan sesuai dengan apa yang dikerjakan sebelumnya tanpa memiliki pemahaman yang lengkap. Secara konseptual subjek dalam menarik jarak titik ke garis yaitu dengan mengaitkan sebuah bentuk segitiga 
agar rumus Pythagoras dapat digunakan.

\section{SIMPULAN DAN SARAN}

Berdasarkan hasil penelitian analisis berpikir pseudo siswa IQ normal dalam pemecahan masalah kedudukan dan jarak titik, garis, dan bidang bahwa siswa IQ normal dalam penelitian ini mengalami berpikir pseudo benar dalam pemecahan masalah. Hal ini dilihat dari jawaban siswa yang benar tetapi setelah diklarifikasi jawaban yang diberikan salah atau kurang tepat. Adapun saran untuk peneliti selanjutnya, hendaknya penelitian lebih luas dilakukan pada hal yang berkaitan dengan berpikir pseudo, misal yang digunakan adalah berpikir pseudo analitik atau yang lainnya. Selain itu subjek penelitian bisa mengambil dari seorang mahasiswa sehingga bisa mendapatkan data berpikir pseudo yang lebih baik.

\section{DAFTAR RUJUKAN}

Husnah, A. (2018). Analisis Berpikir Pseudo Siswa Dalam Memecahkan Masalah Perbandingan Dibedakan Berdasarkan Kemampuan Matematika. Skripsi. Surabaya: Universitas Islam Negeri Sunan Ampel Surabaya.

Kesumawati, N. (2008). Pemahaman Konsep Matematik dalam Pembelajaran Matematika. Prosiding Seminar Nasional Matematika dan Pendidikan Matematika, 2, 231-234.

King, L. A. (2016). Psikologi Umum. Jakarta: Salemba Humanika.

Krismanto. (2008). Pembelajaran Sudut Dan Jarak dalam Ruang Dimensi Tiga di SMA. Yogyakarta: Pusat Pengembangan dan Pemberdayaan Pendidik dan Tenaga Kependidikan Matematika.

Moleong, L. (2014). Metodologi Penelitan Kualitatif. Bandung: Rosdakarya.

Rahmasari, L. (2012). Pengaruh Kecerdasan Intelektual, Kecerdasan Emosi Dan Kecerdasan Spiritual Terhadap Kinerja Karyawan. Majalah Ilmiah Informatika, 3(1).

Rohmatin, D. N. (2012). Profil Berpikir Kritis Siswa SMP Dalam Memecahkan Masalah Geometri Ditinjau Dari Tingkat IQ. Gramatika, 3(1), 1-9.

Siswoyo, B. (2011). Peningkatan hasil belajar sifat-sifat segiempat dengan pendekatan STAD di kelas VII-1 SMP N 2 Kutalimbaru. Jurnal Kreano, 2(2), 89-102, doi: https://doi.org/10.15294/kreano.v2i2.2619

Subanji. (2011). Teori Berpikir Pseudo Penalaran Kovariasional. Malang: Universitas Negeri Malang.

Sugiyono. (2016). Metode Penelitian Pendidikan. Bandung: Alfabeta 
Vinner, S. (1997). The pseudo-conceptual and the pseudo-analytical thought processes in mathematics learning. Educational Studies in Mathematics, 34(2), 97-129. https://doi.org/10.1023/A:1002998529016

Wibawa, K. A. (2016). Karakteristik Berpikir Pseudo Dalam Pembelajaran Matematika. Conference Problem Thinking solving, (Conference Problem Thinking Solving View Paper Mathematics). https://doi.org/ 10.13140/RG. 2. 1.3907.3528 